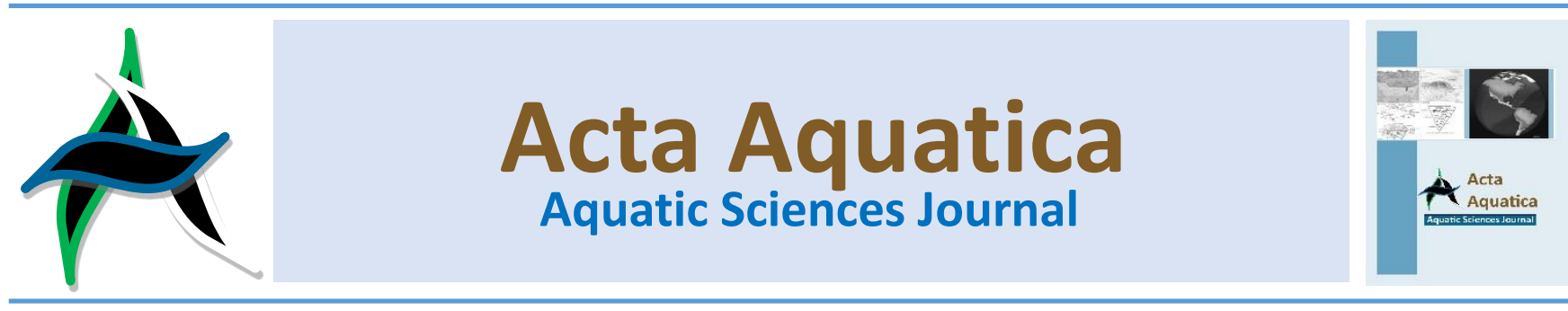

\title{
A preliminary study on the traits of Chamelea gallina (Linnaeus, 1758) in the Gulf of Antalya, Mediterranean Coast of Turkey (Levantine Sea)
}

\author{
Raziye Tanrıverdi ${ }^{a}{ }^{*}$, Mehmet Gökoğlu ${ }^{b}$ and Jale Korun ${ }^{b}$ \\ a Coast Guard Command, Antalya, Turkey \\ ${ }^{b}$ Faculty of Fisheries, Akdeniz University, Turkey
}

\begin{abstract}
This study aimed to examine on some properties and to draw attention to why it cannot create an intensive stock amount of Chamelea gallina (Linnaeus, 1758) in the Gulf of Antalya in the Mediterranean coast of Turkey, Levantine Sea. Specimens of $C$. gallina displayed total shell legths of 6 to $32 \mathrm{~mm}$, mean $14.5 \mathrm{~mm}$ and total weights of 0.1 to $11.44 \mathrm{~g}$, mean $1.82 \mathrm{~g}$. The total shell length and total weight relationship of $C$. gallina was calculated as TW $=0.3333 *$ TSL $2.9894\left(R^{2}=0.9850\right)$. The mean meat yield was found as $12.10 \pm 0.9264 \%$. A small number of $C$. gallina samples were collected. The majority of the collected striped venus were determined as empty shell. It was observed that the razorfish (Xyrichtys novacula) were fed with $C$. gallina during research. Finally, these results may draw attention the reasons why this species cannot form an intensive stock amount. It is thought that the empty shells of the striped venus can be caused from feeding of the razorfish ( $X$. novacula) with C. gallina and environmental factor changes.
\end{abstract}

Keywords: Chamelea gallina; length; weight; meat yield; mediterranean

\section{Introduction}

Chamelea gallina (Linnaeus 1758) is the most produced and demanded bivalve species. C. gallina has a wide area of spread including the East Atlantic Ocean coasts, the British Isles, Norway, Portugal, Morocco, Canary Islands, the Adriatic Sea, the Black Sea and the Mediterranean (Fischer et al., 1987; Deval, 2001; Çolakoğlu and Tokaç, 2010; Biondi and Piero, 2012). This species is found intensively in the Western Black Sea and the Marmara Sea in Turkey (Dalgıç et al., 2006; Dalgıç and Karayücel, 2007; Dalgıç et al., 2009; Çolakoğlu and Tokaç, 2010). The production of mollusca was 5.988.076 tons in the world in 2016 (FAO, 2018). In 1999, the total production of C. gallina was reported to be 45.012 tons by FAO (FAO, 2019). It was began to be harvested for the first time in 1986 in Turkey coasts (Deval, 2001; Dalgıç et al., 2006). It was 34,941 tons in 2017, while the highest production of this species was in 2006 (49.610 tons) and in 2007 (48.549 tons) (BSGM, 2018). C. gallina, despite living in all the coasts of Turkey, the existing production is carried out from the Black Sea (Dalgıç et al., 2009; TUiK, 2016).

\footnotetext{
* Corresponding author: Coast Guard Antalya Group Command, 07070 Sarısu-Konyaalti/Antalya, Turkey.

Tel: +9002422591376 , Fax: +9002422590383

e-mail: rtanriverdi@sg.gov.tr
}

doi: http://doi.org/10.29103/aa.v6i1.1551
C. gallina is one of the important species of the Veneridae family (Çolakoğlu and Tokaç, 2010). It is a mass species on sandy shores up to $20 \mathrm{~m}$ in the Black Sea and Marmara Sea (Boltacheva and Mazlumyan, 2003; Dalgıç and Karayücel, 2007; Çolakoğlu and Tokaç, 2010; Todorova et al., 2015). But, C. gallina is usual, continual and few number in the eastern Mediterranean (Mutlu, 2013).

Since C. gallina is a benthic species, it has to be researched locally (Dalgıç et al., 2009). The growth of bivalves depends on the environmental conditions (nutrient, ground, depth, light, salinity) and reproduction status (Gaspar et al., 2004). Although various studies have been carried out on $C$. gallina, which is commercially cathed on the shores of the Black Sea and the Sea of Marmara of Turkey (Deval, 2001; Tunçer and Erdemir, 2002; Dalgıç et al., 2006; Dalgıç and Karayücel, 2007; Dalgıç et al., 2009; Çolakoğlu and Tokaç, 2010; Dalgıç and Ceylan, 2012; Kasapoğlu and Düzgüneş, 2014; Çolakoğlu and Tokaç, 2014), to date no research has been conducted on $C$. gallina in the Mediterranean coast of Turkey, Levantine Sea. In this study aimed to study on some properties and to draw attention to why it cannot create an intensive stock amount of $C$. gallina in the Gulf of Antalya in the Mediterranean coast of Turkey, Levantine Sea.

\section{Materials and methods}

\subsection{Sampling}

C. gallina samples were collected from sandy ground at a depth of $3 \mathrm{~m}$ with hand and hand dredge by scuba diving from the Gulf of Antalya (36 $52^{\prime} \mathrm{N}$ latitude; $30^{\circ} 41^{\prime} \mathrm{E}$ longitude) on 07 
July, 17 July and 30 November 2018. In summer and autumn seasons, a small number of $C$. gallina species could had been collected. $C$. gallina species could not had been collected because of moving sandy ground due to waves in winter. It was observed that the razorfish (Xyrichtys novacula) were fed with $C$. gallina during research.

C. gallina species (Fig. 1) were collected in July (108 individuals) and in November (10 individuals) by scuba diving.

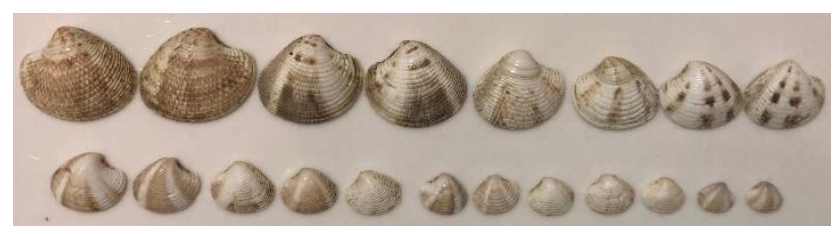

Figure 1. The striped venus (chamelea gallina) from the gulf of antalya.

The collected striped venus were empty shell. Only length measurements of these samples were made. These measurements were used in length calculations. C. gallina species collected in July (117 individuals) and in November (18 individuals) were brought to the laboratory. Weights using 0.01 g precision scales (the total weight (TW), the flesh weight (FW) and the shell weight (SW) and the lengths with $0.1 \mathrm{~mm}$ precision caliper (the total shell length (TSL) (the maximum length along the anterior-posterior axis), the shell height (SH) (maximum distance on the dorsal-ventral axis), the shell width (W) (maximum distance on the lateral axis) and shell thickness (ST) (the middle of each valve) were measured. For flesh and shell weight measurements, all specimens were opened using a knife and the flesh removed with a scalpel.

\subsection{Determination of allometric relationships, statistical analyses and biometric relationships}

Shell lengths and weights relationships were calculated according to the allometric equation: Weight $=a *$ size $e^{b}$ (Pauly, 1984; Berik et al., 2017; Acarlı and Vural, 2018) using the least square regression analysis of Microsoft Excel.

The exponential relationship can be shown by a linear equation because weight is a strong function of length. This equation can be explained by the linearized form log Weight $=\log$ $a+b \log$ size (Pauly, 1984; Berik et al., 2017)

The weight was related to TW, FW and SW. L was also related to size such as TSL, W and SH. The intercept (the first growth coefficient) is $a$, while $b$ is the slope (relative changeable growth rate) (Pauly, 1984; Berik et al., 2017). Allometric relationships were analized one-way ANOVA were used with the software STATIST 7.1. All statistical analyzes were evaluated at the $P<0.05$ levels (SPPS 15.0) (Watts et al., 1998). Meat yield (MY) equation was used as:

$M Y=[$ Meat weight $(g) /$ Total weight $(g)] \times 100$ (Acarlı et al., 2011; Berik et al., 2017).

Shell component index $(\mathrm{SCl})=[$ Shell wet weight $(\mathrm{g}) /$ Total weight (g)] $x 100$ (Gaikwad and Kamble, 2014).

\section{Result and discussion}

\subsection{Shell dimensions and allometric relations}

Specimens of $C$. gallina displayed total shell legths of 6 to $32 \mathrm{~mm}$, mean $14.5 \mathrm{~mm}$ and total weights of 0.1 to $11.44 \mathrm{~g}$, mean $1.82 \mathrm{~g}$ in the material collected (Table 1 ).
Table 1

Descriptive statistics of Chamelea gallina from the Gulf of Antalya.

\begin{tabular}{ccccc}
\hline Mesurements & $\mathrm{N}$ & Minimum & Maximum & Mean (SE) \\
\hline TSL & 253 & 6 & 32 & $14.5 \pm 0.030$ \\
SH & 253 & 6 & 28 & $13 \pm 0.027$ \\
W & 253 & 4 & 18 & $8.1 \pm 0.016$ \\
ST & 253 & 0.5 & 2 & $1.1 \pm 0.002$ \\
TW & 140 & 0.1 & 11.44 & $1.82 \pm 0.154$ \\
SW & 137 & 0.08 & 5.71 & $1.16 \pm 0.092$ \\
FW & 138 & 0.01 & 1.36 & $0.22 \pm 0.022$ \\
\hline
\end{tabular}

TSL, Total shell length $(\mathrm{mm}) ; \mathrm{SH}$, Shell height $(\mathrm{mm}) ; \mathrm{W}$, Shell Width $(\mathrm{mm}) ; \mathrm{ST}$, Shell Thickness (mm); TW, Total Weight (g); SW, Shell Weight (g); FW, Flesh weight of C. gallina (without shell) (g)

It was determined that this species had the maximum length/maximum mean length and the maximum weight/maximum mean weight values in the Western Marmara Sea (Table 2). The minimum length and minimum weight values were found in Marmara North Sea (Table 2). The minimum of mean length and minimum mean weight values were detected in the Mediterranean coast of Turkey, Levantine Sea (Table 2).

Table 2

Length-weight measurement values determined by other investigators of Chamelea gallina.

\begin{tabular}{|c|c|c|c|c|}
\hline Area & $\begin{array}{l}\text { Latitude } \\
\left({ }^{\circ}\right)\end{array}$ & $\begin{array}{c}\mathrm{L} \\
\operatorname{mean} \pm \text { Std. }(\mathrm{mm}), \\
(\text { min.-max. }), \mathrm{N}\end{array}$ & $\begin{array}{l}\text { TW mean } \pm \text { Std. } \\
\text { (g), (min.-max.), } \\
\mathrm{N}\end{array}$ & Researchers \\
\hline $\begin{array}{l}\text { North } \\
\text { Marmara Sea }\end{array}$ & 40 & $\begin{array}{c}20.09(3.6-34.5) \\
N: 2887\end{array}$ & $\begin{array}{c}3.1(0.01-12.1) \\
\mathrm{N}: 2887\end{array}$ & $\begin{array}{l}\text { Deval, 1995; } \\
\text { Deval, } 2001\end{array}$ \\
\hline $\begin{array}{l}\text { West Marmara } \\
\text { Sea }\end{array}$ & 40 & $\begin{array}{c}28(21.1-36.9) \\
\mathrm{N}: 91\end{array}$ & $\begin{array}{l}6.84(2.47- \\
15.41) \mathrm{N}: 91\end{array}$ & $\begin{array}{l}\text { Tunçer and } \\
\text { Erdemir, } 2002\end{array}$ \\
\hline West Black Sea & 41 & $\begin{array}{c}19.56(6.3-31.5) \\
N: 424\end{array}$ & $\begin{array}{c}2.46(0.08-8.67) \\
N: 424\end{array}$ & $\begin{array}{l}\text { Dalgıç et al., } \\
\text { 2006; Dalgıç et } \\
\text { al., } 2009\end{array}$ \\
\hline $\begin{array}{l}\text { Middle Black } \\
\text { Sea }\end{array}$ & 42 & $\begin{array}{c}18.45(6.5-28.7) \\
\mathrm{N}: 1432\end{array}$ & $\begin{array}{c}2.34(0.09-6.26) \\
N: 1432\end{array}$ & $\begin{array}{l}\text { Dalgıç et al., } \\
\text { 2006; Dalgıç et } \\
\text { al., } 2009\end{array}$ \\
\hline $\begin{array}{l}\text { Middle Black } \\
\text { Sea }\end{array}$ & 41 & $\begin{array}{c}18.48(7.4-29.1) \\
N: 596\end{array}$ & $\begin{array}{c}2.16(0.13-8.43) \\
N: 596\end{array}$ & $\begin{array}{l}\text { Dalgıç et al., } \\
\text { 2006; Dalgıç et } \\
\text { al., } 2009\end{array}$ \\
\hline $\begin{array}{l}\text { Eastern Black } \\
\text { Sea }\end{array}$ & 41 & $\begin{array}{c}17.96(6.4-30) \\
\mathrm{N}: 1332\end{array}$ & $\begin{array}{c}1.88(0.09-57) \\
\mathrm{N}: 1332\end{array}$ & $\begin{array}{c}\text { Dalgıç and } \\
\text { Karayücel, } 2007\end{array}$ \\
\hline $\begin{array}{l}\text { West Marmara } \\
\text { Sea }\end{array}$ & 40 & $\begin{array}{c}23.9(7-39) \\
\mathrm{N}: 3325\end{array}$ & $\begin{array}{c}4.85(0.3-21.05) \\
\mathrm{N}: 3325\end{array}$ & $\begin{array}{l}\text { Çolakoğlu and } \\
\text { Tokaç, } 2010\end{array}$ \\
\hline $\begin{array}{l}\text { East and } \\
\text { Middle Black } \\
\text { Sea }\end{array}$ & 41 & $\begin{array}{c}17.6(7-30) \\
N: 628\end{array}$ & $\begin{array}{c}1.95(0.2-4.82) \\
\mathrm{N}: 628\end{array}$ & $\begin{array}{l}\text { Kasapoğlu and } \\
\text { Düzgüneş, } 2013\end{array}$ \\
\hline Monfalcone & 45 & $26.85, \mathrm{~N}: 40$ & & Gizzi et al., 2016 \\
\hline Chioggia & 45 & $26.14, \mathrm{~N}: 40$ & - & Gizzi et al., 2016 \\
\hline Goro & 44 & $26.06, \mathrm{~N}: 40$ & - & Gizzi et al., 2016 \\
\hline Cesenatico & 44 & $26.52, \mathrm{~N}: 40$ & - & Gizzi et al., 2016 \\
\hline San Benedetto & 43 & $26.39, \mathrm{~N}: 40$ & - & Gizzi et al., 2016 \\
\hline Capoiale & 41 & $26.40, N: 40$ & - & Gizzi et al., 2016 \\
\hline $\begin{array}{l}\text { Gulf of } \\
\text { Antalya, } \\
\text { Mediterranean }\end{array}$ & 36 & $\begin{array}{c}14.5 \pm 0.030(6- \\
32), \mathrm{N}: 253\end{array}$ & $\begin{array}{c}1.82 \pm 0.154 \\
(0.1-11.44) \\
N: 140\end{array}$ & In this study \\
\hline
\end{tabular}

L: Lenght, TW: Total weight, $\mathrm{N}$ : Number of individuals

In this study, the mean shell width and the mean shell height were found as $8.1 \pm 0.016 \mathrm{~mm}$ ( $\mathrm{min} .4 \mathrm{~mm}$-mak. $18 \mathrm{~mm}$ ) and $13 \pm 0.027 \mathrm{~mm}$ (min. $6 \mathrm{~mm}$-mak. $28 \mathrm{~mm}$ ), respectively (Table 1). The maximum mean shell width in the Western Marmara Sea and the minimum mean shell width in Capoiale were determined as $28 \mathrm{~mm}$ and $6.13 \mathrm{~mm}$, respectively (Table 2).

It was detected that the maximum mean shell height in 
the West Marmara Sea was $21.8 \mathrm{~mm}$ (Table 2) and the minimum mean shell height in the Mediterranean coast of Turkey, Levantine Sea was $13 \mathrm{~mm}$ (Table 1). These results showed that the maximum mean shell width and the maximum mean shell height were in the Western Marmara Sea (Table 2), the minimum mean shell width was in Capoiale (Table 2) and the minimum mean shell height was in the Mediterranean coast of Turkey, Levantine Sea (Table 1). In this study, the mean shell thickness was detected as $1.1(0.002) \mathrm{mm}$ (Table 1$)$. It was found that the mean shell thickness $(1.06 \mathrm{~mm}$ ) was lower in Capoiale (Table 2).

In this study, the TSL-TW relationship was calculated as $T W=0.3333 *$ TSL $2.9894\left(R^{2}=0.9850\right)$. Length and weight relationship results demonstrated that this species showed allometric growth in the sampling area. All the allometric relationships between shell mesurements and weight were given in Table 3.

It was found that this species had a negative allometric growth in the North Marmara Sea, West Marmara Sea, Eastern Black Sea, East and Middle Black Sea and Marmara Sea (Table 4). In this study, all the slopes of the regression lines were significantly different from zero. The TSL, the SH and the $\mathrm{W}$ all showed a strong correlation with the TW, the FW and the SW. However, while the ST was in a small relationship with the TSL and the FW, the TW was slightly better for C. gallina in the Mediterranean coast of Turkey, Levantine Sea (Table 3).

A strong relationship was found between the regression analysis of the shell length (TSL, W and SH) and weight (TW, FW and SW) in the North Marmara Sea, West Marmara Sea, Eastern Black Sea and Marmara Sea (Table 4).

Table 3

Allometric relationships of Chamelea gallina between body measurements (total shell length, height, width and thickness) and weight in the Gulf of Antalya.

\begin{tabular}{|c|c|c|c|c|c|}
\hline Relationship & $\mathrm{n}$ & $a$ & $\mathrm{~b}$ & $\mathrm{R}^{2}$ & $P$ \\
\hline \multicolumn{6}{|c|}{ Total weight (TW) } \\
\hline TW on TSL & 140 & 1.4454 & 0.3294 & 0.9850 & $P \leq 0.005$ \\
\hline TW on SH & 140 & 1.2964 & 0.3308 & 0.9723 & $P \leq 0.005$ \\
\hline TW on W & 140 & 0.8043 & 0.3229 & 0.9722 & $P \leq 0.005$ \\
\hline TW on ST & 140 & 0.1102 & 0.2856 & 0.6907 & $P \leq 0.005$ \\
\hline TW on SW & 137 & 0.6784 & 1.0085 & 0.9908 & $P \leq 0.005$ \\
\hline TW on FW & 138 & 0.1018 & 1.1650 & 0.8602 & $P \leq 0.005$ \\
\hline \multicolumn{6}{|c|}{ Flesh weight (FW) } \\
\hline FW on TSL & 138 & 2.5285 & 2.2416 & 0.8400 & $P \leq 0.005$ \\
\hline $\mathrm{FW}$ on $\mathrm{SH}$ & 138 & 2.2802 & 0.2439 & 0.8341 & $P \leq 0.005$ \\
\hline FW on W & 138 & 1.3921 & 0.2373 & 0.8372 & $P \leq 0.005$ \\
\hline FW on ST & 138 & 0.1779 & 0.2077 & 0.5877 & $P \leq 0.005$ \\
\hline FW on TW & 138 & 5.5322 & 0.7383 & 0.8602 & $P \leq 0.005$ \\
\hline FW on SW & 135 & 3.6550 & 0.7307 & 0.8496 & $P \leq 0.005$ \\
\hline \multicolumn{6}{|c|}{ Total shell Lenght (TSL) } \\
\hline TSL on SH & 253 & 0.8905 & 1.0090 & 0.9704 & $P \leq 0.005$ \\
\hline TSL on W & 253 & 0.5727 & 0.9327 & 0.9591 & $P \leq 0.005$ \\
\hline TSL on ST & 253 & 0.0863 & 0.7137 & 0.5583 & $P \leq 0.005$ \\
\hline TSL on TW & 140 & 0.3333 & 2.9894 & 0.9850 & $P \leq 0.005$ \\
\hline TSL on SW & 137 & 0.2248 & 3.0024 & 0.9742 & $P \leq 0.005$ \\
\hline TSL on FW & 138 & 0.0284 & 3.4768 & 0.8400 & $P \leq 0.005$ \\
\hline
\end{tabular}

TSL, Total shell length; W, Shell width; SH, Shell height; ST, Shell thickness; TW, total weight; SW, Shell Weight; FW, flesh weight
Table 4

Parameters of allometric relationships of Chamelea gallina between body measurements by others resaershers determined.

\begin{tabular}{cccccc}
\hline Relationship & $\mathrm{N}$ & $\mathrm{a}$ & $\mathrm{b}$ & $\mathrm{r}^{2}$ & Researcher \\
\hline SH on TSL & 536 & 0.69 & 1.024 & 0.998 & \\
W on TSL & 232 & 0.303 & 1.005 & 0.984 & \\
SW on TSL & 322 & 3.544 & 2.900 & 0.992 & \\
FW on TSL & 42 & 4.771 & 3.265 & 0.770 & Deval, 2001 \\
TW on TSL & 536 & 3.383 & 2.902 & 0.993 & \\
SW on TW & 367 & 0.137 & 0.976 & 0.995 & \\
FW on TW & 42 & 1.039 & 1.180 & 0.807 & \\
\hline TSL on TW & 91 & 0.0004 & 2.9669 & 0.95 & \\
TSL on SW & 91 & 0.0004 & 2.9083 & 0.95 & Tuncer and \\
TSL on FW & 91 & $5 \mathrm{E} .05$ & 3.1814 & 0.94 & Erdemir, 2002 \\
TSL on W & 91 & 0.8942 & 5.4158 & 0.89 & \\
\hline TW on TSL & 1332 & -3.1408 & 2.6918 & 0.968 & \\
\hline SH on TSL & 1332 & -0.0479 & 1.0080 & 0.998 & Dalgıç and \\
W on TSL & 1332 & -0.3680 & 1.0267 & 0.973 & Karayücel, 2007 \\
\hline FW on TSL & 1332 & -4.2724 & 2.7123 & 0.932 & \\
\hline TW on TSL & 628 & 0.4520 & 2.365 & 0,954 & Kasapoğlu and \\
TSüzgüneş, 2013
\end{tabular}

TSL, Total shell length; W, Shell width; SH, Shell height; ST, Shell thickness; TW, tota weight; SW, Shell Weight; FW, flesh weight

\subsection{Meat yield}

In this study, it was found that mean FW of $C$. gallina was $0.22 \pm 0.022 \mathrm{~g}$ (min.0.01 g-mak.1.36 g, N:138), mean MY was $12.10 \pm 0.9264 \%$ (min.2.17\%-mak.85.36\%, N:138), the mean SW was $1.16 \pm 0.092 \mathrm{~g}$ ( $\min .0 .08 \mathrm{~g}$-mak.5.71 g, N:137) and the mean $\mathrm{SCl}$ was $68.17 \pm 0.5192 \%$ (min.46.66\%-mak.99.52\%, N:137). It was determined that the mean meat weight of $C$. gallina ( $\mathrm{N}: 1655)$ was $0.66 \pm 0.01 \mathrm{~g}$ (min.0.09 g-mak.2.53 g) and the mean meat yield was $19.10 \pm 0.43 \%$ (min.0.78\%-mak. $85.60 \%$ ) in the West Sea of Marmara (Çolakoğlu and Tokaç, 2014). It was determined that the mean meat weight of $C$. gallina $(\mathrm{N}: 1332)$ was $0.15 \pm 0.01 \mathrm{~g}$ (min. $0.01 \mathrm{~g}-0.46 \mathrm{~g}$ ), the mean meat yield was $8.04 \%$ and the mean shell weight was $1.22 \pm 0.04 \mathrm{~g}$ (min. $0.03 \mathrm{~g}$-mak.4.01 g) in the Eastern Black Sea (Dalgıç and Karayücel, 2007).

When these studies were evaluated, the mean FW and the mean MY in the West Sea of Marmara and the mean SW in the Eastern Black Sea were observed to be maximum. The minimum mean $\mathrm{FW}$ and the minimum MY were determined in the Eastern Black Sea and the minimum mean SW was found in the Mediterranean coast of Turkey, Levantine Sea. In Bivalves, MY varies according to environmental conditions, breeding season, nutritional status and species (Acarlı et al., 2011; Berik et al., 2017).

Latitude is the main factor affecting solar radiation and water temperature change (Caroselli et al., 2016). It is widely used as monitoring and control parameter in ecological studies (Caroselli et al., 2016; Gizzi et al., 2016). It has a notable effect for organism biology (Caroselli et al., 2016). The shell morphology of the molluscs is particularly sensitive to 
environmental conditions (depth, discharge, wave exposure, bottom structure, sediment, $\mathrm{pH}$ and temperature changes) (Gizzi et al., 2016). Water temperature in the crustal growth of $C$. gallina has a dominant role. Shell growth slows down strongly at temperatures below $10^{\circ} \mathrm{C}$. Energy absorption decreases at temperatures above $28-27^{\circ} \mathrm{C}$ and energy spending increases with respiratory tract. Thus, the shell growth stops (Deval, 2001; Gizzi et al., 2016). High temperature affects calcification by affecting the presence of nutrients that play a key role in the growth of the molluscs (Gizzi et al., 2016). C. gallina has a relatively low tolerance to high temperature compared to other bivalve species (Moschino and Marin, 2006; Gizzi et al., 2016). Several studies showed that changes in the abiotic environmental factors such as temperature, salinity and oxygen affected the immune parameters by making $C$. gallina more susceptible to diseases and infections (Gizzi et al., 2016; Matozzo and Marin, 2011). It was observed that the salinity and temperature as the first component and the chlorophyll-a concentration as the second affected the growth of $C$. gallina. This species had the lowest growth rate in the Black Sea, which had low temperature, salinity and chlorophyll-a values, whereas it showed the highest growth rate in the Gulf of Cadiz, which was more hot, salty and chlorophyll-a (Delgado et al., 2015).

In Turkey, sea water temperatures were identified as the mean $5.2^{\circ} \mathrm{C}\left(\min .13 .8^{\circ} \mathrm{C}\right.$ - mak.16.4 $\left.{ }^{\circ} \mathrm{C}\right)$ in the Black Sea, the mean of $15.5^{\circ} \mathrm{C}\left(\min .14 .4^{\circ} \mathrm{C}\right.$-mak. $\left.17.2^{\circ} \mathrm{C}\right)$ in the Sea of Marmara, the mean of $18.5^{\circ} \mathrm{C}\left(\min .17 .7^{\circ} \mathrm{C}-\right.$ mak.19.4 $\left.{ }^{\circ} \mathrm{C}\right)$ in the Aegean Sea, the mean $22.04{ }^{\circ} \mathrm{C}\left(\min .20 .6{ }^{\circ} \mathrm{C}\right.$-mak.22.3 $\left.{ }^{\circ} \mathrm{C}\right)$ in the Mediterranean (MGM, 2018). The total mean radiation intensity of Turkey was found $1.120 \mathrm{kWh} \mathrm{m}^{2}$-year in the Black Sea, $1.168 \mathrm{kWh} \mathrm{m}^{2}$-year in the Sea of Marmara, $1.304 \mathrm{kWh} \mathrm{m}^{2}$-year in the Aegean Sea, 1.390 $\mathrm{kWh} \mathrm{m}^{2}$-year in the Mediterranean (BAKA, 2011). Turkey has four regions with the sea coast. The latitude value of the Central and Eastern Black Sea Region is large and humid. For this reason, the least radiation area is the area. Marmara and North Aegean Region have a slightly better radiation than the Black Sea. Southern Aegean and Western Mediterranean Regions receive moderate radiation. Eastern Mediterranean Region is a region with good radiation values (Aksungur et al., 2019).

The chlorophyll-a concentrations in the surface layer (0$10 \mathrm{~m}$ mean) were determined in the Aegean Sea (0-20 $\mu \mathrm{gL})$ (CBD, 2018a) , (0-12 $\mu \mathrm{gL})$ in the Marmara Sea (CBS, 2018c), $(0-4 \mu \mathrm{gL})$ in the Black Sea (CBS, 2018b) and (0-1.2 $\mu \mathrm{gL}$ ) in the Mediterranean (CBS, 2018d) between the years 2014-2017 in Turkey. The dissolved oxygen values for 2017 were detected 5-10 mg L at 0$70 \mathrm{~m}$ in the Black Sea (CBS, 2018b), 0-12 mg L for about 0-50 m in Marmara Sea (CBS, 2018c), 4.4-8.5 mg L approximately 0-100 $\mathrm{m}$ in the Aegean Sea (CBS, 2018a), surface water oxygen saturation level $97-112 \%$ and concentration values $5.74-6.7 \mathrm{mg} \mathrm{L}$ at $0-10 \mathrm{~m}$ in the Mediterranean (CBS, 2018d). The salinity values were found $17-18 \%$ in surface waters of the Black Sea $(0-40 \mathrm{~m})$, $22 \%$ in surface waters $(0-20 \mathrm{~m})$ of the Marmara Sea, $36.1-39.2 \%$ in surface waters of the Aegean Sea $(0-50 \mathrm{~m})$ and approx. 38.5$39.0 \%$ in surface waters of the Mediterranean $(0-300 \mathrm{~m})$ (Soydemir, 2004).

When these studies were evaluated, it was found that the sea water temperature, the radiation intensity and the salinity value were determined as the highest while the chlorophyll-a concentrations and dissolved oxygen values were found as the lowest in the Mediterranean coast of Turkey, Levantine Sea. In this study, a small number of $C$. gallina samples were could had been collected. Mutlu (2013) reported that $C$. gallina had few numbers with 17 samples collected using the epibentic sledge at a depth of 5-10 m between February 2000 and April 2002 monthly in the eastern Mediterranean. In this study, the majority of the collected striped venus were determined as empty shell. It was found a large amount of empty striped venus in the Eastern Black Sea of Turkey (Dalgıç and Karayücel, 2007). Similar incidents had also been reported from Italy (Angioni et al., 2010). Oxygen deficiency and other natural events were considered to be the cause (Dalgıç and Karayücel, 2007; Angioni et al., 2010). It was observed that the razorfish (Xyrichtys novacula) were fed with C. gallina during research. It was reported that the razorfish was fed with bivalves in the Gulf of Antalya (Üstüner et al., 2018) and C. gallina in the Strait of Sicily in the Mediterranean (Beltrano et al., 2006). Finally, these results may draw attention the reasons why this species cannot form an intensive stock amount. It is thought that the empty shells of the striped venus can be caused from feeding of the razorfish ( $X$. novacula) with $C$. gallina and environmental factor changes (temperature, salinity, oxygen and chlorophyll-a).

\section{Acknowledgments}

I would like to thank for Aysun Küçükdermenci for statistical calculations from the Aquaculture Faculty of the Aegean University.

\section{Bibliography}

Acarlı, S., Lök, A., Küçükdermenci, A., Yıldız, H., Serdar, S., 2011. Comparative growth, survival and condition index of flat oyster, Ostrea edulis (Linnaeus 1758) in Mersin Bay, Aegean Sea, Turkey. Journal of the Faculty of Veterinary Medicine, Kafkas University 17(2), 203-210. doi:10.9775/kvfd.2010.2806.

Acarlı, S., Vural, P., 2018. Morphometric analysis of Ensis marginatus (Pennant, 1777) from Gallipolli, Çanakkale, Turkey. p. 391-394. In: Proceeding Book, International Marine and Freshwater Sciences Symposium, KemerAntalya, 18-21 Oct, pp. 391-394.

Aksungur, K.M., Kurban, M., Filik, B., 2019. Analysis and evaluation of solar radiation data in different regions of Turkey. (http://www.academia.edu (accessed 05 February 2019)).

Angioni, S.A., Giansante, C., Ferri, N., 2010. The Clam (Chamelea gallina): Evaluation of the effects of solids suspended in seawater on Bivalve Molluscs. Veterinaria Italiana 46(1), 101-106.

BAKA, 2011. Solar Energy Sector Report. (http://baka.org.tr/uploads/1303486512GUNESTURKCE-KATALOG.pdf (accessed 20 February 2019)).

Beltrano, A.M., Cannizzaro, L., Vitale, S., Milazzo, A., 2006. Preliminary study on the feeding habits of cleaver wrasse, Xyrichthys novacula (Pisces: Labridae) in the Strait of Sicily (Mediterranean Sea). Electronic Journal of Ichthyology 2, 50-54.

Berik, N., Çankırılıgil, E.C., Gül, G., 2017. Meat yield and shell dimension of smooth scallop (Flexopecten glaber) caught from Çardak Lagoon in Çanakkale, Turkey. Journal of Aquaculture and Marine Biology 5(3), 00122. doi: 10.15406/jamb.2017.05.00122.

Biondi, S., Piero, D.D., 2012. Survey on Chamelea gallina bedsin the Lignano Area (Gulf of Trieste, Adriatic Sea). Annales Series Historia Naturalis 22(1), 35-44. 
Boltacheva, N.A., Mazlumyan, S.A., 2003. The Growth and longevity of Chamelea gallina (Mollusca, Veneridae) in the Black Sea. Vestnik zoologii 37(3), 71-74.

BSGM, 2018. Fishery and Aquaculture Statistics. (https://www.tarimorman.gov.tr/sgb/Belgeler/SagMen uVeriler/BSGM.pdf (accessed 20 February 2019)).

Caroselli, E., Ricci, F., Brambilla, V., Mattioli, G., Levy, O., Falini, G., Dubinsky, Z., Goffredo, S., 2016. Relationships between growth, population dynamics, and environmental parameters in the solitary nonzooxanthellate scleractinian coral Caryophyllia inornata along a latitudinal gradient in the Mediterranean Sea. Coral Reefs 35, 507-519. doi: 10.1007/s00338-015-13939.

CSB, 2018a. Aegean Sea, Sea Quality Bulletin. (http://webdosya.csb.gov.tr/db/ced/dokumanlar/denizkalitesi-8230-5262-20180202112143.pdf (accessed 20 February 2019)).

CSB, 2018b. Black Sea, Sea Quality Bulletin. (http://webdosya.csb.gov.tr/db/ced/menu/denizkalitesi-bulteni-2018_karadeniz_20180131045016.pdf (accessed 20 February 2019)).

CSB, 2018c. Marmara Sea, Sea Quality Bulletin. (http://webdosya.csb.gov.tr/db/ced/dokumanlar/denizkalitesi-8230-5261-20180202111413.pdf (accessed 20 February 2019)).

CSB, 2018d. Mediterranean, Sea Quality Bulletin. (http://webdosya.csb.gov.tr/db/ced/dokumanlar/denizkalitesi-8230-5263-20180202112231.pdf (accessed 20 February 2019)).

Çolakoğlu, S., Tokaç, A., 2010. Some population parameters of the striped venus (Chamelea gallina L., 1758) in the West Marmara Sea. E.U. Journal of Fisheries and Aquatic Sciences 27(2), 65-71.

Çolakoğlu, S., Tokaç, A., 2014. Properties growth of populations the striped venus (Chamelea gallina L., 1758) and the wedge clam (Donax trunculus L., 1758) in the West Marmara Sea. Journal of FisheriesSciences.com 8(1), 2741. doi: 10.3153/jfscom.2014004.

Dalgıç, G., Ceylan, Y., 2012. Seasonal discards and by-catch of striped venus clam (Chamelea gallina) (Mollusca, Bivalves) fishery in the Black Sea. Turkish Journal of Fisheries and Aquatic Sciences 12, 811-816.

Dalgıç, G., Karayücel, S., 2007. Investigations on the stocks of the striped venus (Chamelea gallina L., 1753) in Ordu's coastal zone of the Eastern Black Sea. Journal of Fisheries International 2(1), 12-16.

Dalgıç, G., Okumuş, İ., Karayücel, S., 2006. A View to the striped venus (Chamelea gallina L., 1753) processing industry in Turkey. E.U. Journal of Fisheries and Aquatic Sciences 23(1/3), 397-400.

Dalgıç, G., Okumuş, I.., Karayücel, S., 2009. The effect of fishing on growth of the clam Chamelea gallina (Bivalvia: Veneridae) from the Turkish Black Sea coast. Journal of the Marine Biological Association of the United Kingdom 1-5. doi: 10.1017/S0025315409000939.

Delgado, M., Silva, L., Moura, P., Sánchez-Leal, R.F., Gaspar, M.B., 2015. Variation of growth performance of the striped venus clam Chamelea gallina (Mollusca: Bivalvia) (Linnaeus, 1758) in relation to environmental variables along the southern part of Its geographic range. Vie Et Milieu - Life And Environment 65(4), 201-210.

Deval, M.C., 1995. Age and shell development of Chamelea gallina Linneaeus, 1758 in the Northern Marmara Sea. PhD Thesis, Istanbul University, Turkey.

Deval, M.C., 2001. Shell growth and biometry of the striped Venus gallina $(\mathrm{L})$ in the Marmara Sea, Turkey. Journal of Shellfish Research 20(1), 155-159.

FAO, 2018. Fishery and Aquaculture Statistics 2016. FAO Yearbook, Rome, Italy.

FAO, 2019. Chamelea gallina. (http://www.fao.org (accessed 05 February 2019)).

Fischer, W., Bauchot, M.L., Schneider, M., 1987. Fiches FAO D'identification des Espèces Pour les Besoins de la Pêche, (Révision 1), Méditerranée et Mer Noire, Zone de Pêche 37, Végétaux et Invertébrés. Publication préparée par la $\mathrm{FAO}$, résultat d'un accord entre la $\mathrm{FAO}$ et la Commission des Communautés Européennes (Projet GCP/INT/422/EEC) financée conjointement par ces deux organisations.

Gaikwad, S.S., Kamble, N.A., 2014. In Vitro assessment of water current on growth and biometric relationship among Molluscs. Journal of Research in Biology 4(7), 1475-1486.

Gaspar, M.B., Pereira, A.M., Vasconcelos, P., Monteiro, C.C., 2004. Age and growth of Chamelea gallina from the Algarve coast (Southern Portugal): Influence of seawater temperature and gametogenic cycle on growth rate. Journal of Molluscan Studies 70(4), 371-377.

Gimin, R., Mohan, R., Thinh, L.V., Griffiths, A.D., 2004. The relationship of shell dimensions and shell volume to live weight and soft tissue weight in the mangrove clam, Polymesoda erosa (Solander, 1786) from Northern Australia. NAGA, WorldFish Center Quarterly 27(3and4), 32-35.

Gizzi, F., Caccia, M.G., Simoncini, G.A., Mancuso, A., Reggi, M., Fermani, S., Brizi, L., Fantazzini, P., Stagioni, M., Falini, G., Piccinetti, C., Goffredo, S., 2016. Shell properties of commercial clam Chamelea gallina are influenced by temperature and solar radiation along a wide latitudinal gradient. Scientific Reports 6, 36420. doi 10.1038/srep36420.

Kasapoğlu, N., Düzgüneş, E., 2014. Length-weight relationships of marine species caught by five gears from the Black Sea. Mediterranean Marine Science 15(1), 95-100. doi: http://dx.doi.org/10.12681/mms.463.

Matozzo, V., Marin, M.G., 2011. Bivalve immune responses and climate changes: is there a relationship. Invertebrate Survival Journal 8, 70-7. 
MGM, 2018. Sea Water Temperatures. (https://www.mgm.gov.tr/veridegerlendirme/il-veilceler-istatistik.aspx?k=K (accessed 20 February 2019)).

Moschino, V., Marin, M.G., 2006. Seasonal changes in physiological responses and evaluation of "well-being" in the venus clam Chamelea gallina from the Northern Adriatic Sea. Comparative Biochemistry and Physiology Part A 145, 433-440. doi: 10.1016/j.cbpa.2006.07.021.

Üstüner, H., Gökoğlu, M., Çetin, E.K., Yılmaz, D., Sarıgöl, B., Özcan, H., 2018. Investigation of the prey-predator relationship between predator Xyrichtys novacula (L., 1758) and lesepsian gastropod Strombus persicus (Swainson, 1821). European International Journal of Science and Technology 7(3), 41-50.

Pauly, D., 1984. Fish Population Dynamics in Tropical Waters: a Manual for Use With Programmable Calculators. ICLARM Studies and Reviews 8, International Center for Living Aquatic Resources Management Studies and Reviews Press., Makati, Metro Manila, Philippines.

Soydemir, N., 2004. October 2000 of Turkey's seas in open waters phytoplankton composition. Master's Thesis. Mersin University, Mersin, Turkey.

Todorova, V., Dimitrov, L., Doncheva, V., Trifonova, E., Prodanov, B., 2015. Benthic habitat mapping in the Bulgarian Black Sea. In: Proceedings of the Twelfth International Conference on the Mediterranean Coastal Environment MEDCOAST'15, 06-10 Oct, Varna, Bulgaria, pp. 251- 262.

TUiK, 2016. Fishery statistics. (http://www.tuik.gov.tr (accessed 20 February 2019)).

Tunçer, S., Erdemir, C.Ç., 2002. A Preliminary study on some properties for Chamelea gallina (L.,) (Bivalvia: Verenidae) from Karabiga-Çanakkale. Turkish Journal of Fisheries and Aquatic Sciences 2, 117-120.

Watts, S.A., Boettger, S.A., McClintock, J.B., Lawrence, J.M., 1998. Gonad production in the sea urchin Lytechinus variegatus (Lamarck) fed prepared diets. Journal Shellfish Research 17, 1591-1595. 